\title{
Wokół pojęcia profilaktyki niedostosowania społecznego dzieci i młodzieży
}

\author{
Prevention of social maladjustment of children and teenagers
}

\section{Streszczenie:}

Problem niedostosowania społecznego dzieci i młodzieży oraz działań profilaktycznych w tym obszarze są niezmiernie istotnym zagadnieniem we współczesnej szkole. W swoich rozważaniach autorki szukają odpowiedzi na pytania: czym jest profilaktyka, jakie są sposoby jej rozumienia i na czym polega. Analizują i ukazują możliwości podniesienia skuteczności profilaktyki w praktyce szkolnej przy uwzględnieniu prewencji.

\begin{abstract}
:
The issue of social maladjustment of children and teenagers on the one hand, and the preventive actions to be taken so as to hinder the social maladjustment, are of high importance in the contemporary school. The authors of this paper aim at answering the questions of what prevention is, what it depends upon and how it should be understood. They analyse and present the effectiveness of prevention in the school environment.
\end{abstract}

Słowa kluczowe: niedostosowanie społeczne, profilaktyka, prewencja

Keywords: the specificity of work, burnout, nurse

\section{Wprowadzenie}

Nieprzystosowanie społeczne dzieci i młodzieży stanowi poważne zagrożenie w dzisiejszym zglobalizowanym świecie i naszej przyszłości. Zagrożenie wypływające z tego faktu stanowi wyzwanie dla naukowców i badaczy społecznych ${ }^{1}$. Powód głębszego zainteresowania się tym problemem to rosnąca liczba różnych przejawów dysfunkcjonalności dzieci i młodzieży oraz nadal mało efektywne oddziaływania wychowawcze, mimo podejmowanych różnorodnych działań profilaktycznych kompensacyjnych, opiekuńczych, medycznych czy terapeutycznych. Również opracowywane i realizowane obowiązkowo szkolne programy profilaktyczne, które powinny uwzględniać działania uczniów, nauczycieli i rodziców a wprowadzone od 1 września 2002 r. nie spełniają oczekiwań w tym obszarze. Konsekwencją tego jest poszukiwanie nowych

\footnotetext{
${ }^{1}$ W.W. Szczęsny, Zarys resocjalizacji z elementami patologii społecznej i profilaktyki, Warszawa 2003,s. 29.
} 
rozwiązań, które wpłynęłyby na zminimalizowanie rozmiarów niedostosowania społecznego wśród dzieci i młodzieży.

Zgłaszane są różnego rodzaju inicjatywy oraz tworzone programy profilaktyczne a „Ich nadrzędnym zadaniem jest kształtowanie postaw, które ochronią przed powstawaniem i rozwojem negatywnych zachowań i zjawisk"2. Ponadto $\mathrm{w}$ związku z potrzebą kształcenia społeczeństwa w zakresie edukacji profilaktycznej, wzrasta liczba opracowań naukowych i popularnonaukowych.

\section{Teoretyczne rozważania o niedostosowaniu społecznym}

Dla potrzeb pracy określimy definicyjnie kluczowe pojęcia: niedostosowanie społeczne, profilaktyka niedostosowania społecznego, prewencja.

W literaturze przedmiotu i języku potocznym termin „niedostosowanie społeczne" bywa często zamiennie używany z określeniem „nieprzystosowanie społeczne". Funkcjonują też takie określenia, jak „zaburzenia w zachowaniu", „zachowania dewiacyjne”, „zaburzenia socjalizacji", „zjawiska patologii społecznej", „przestępczość nieletnich", „podkultury młodzieżowe", „zła adaptacja, społeczna", „patologia zachowania" itp. ${ }^{3}$.

Dla naszych rozważań przyjmiemy definicję Lesława Pytki następującej treści: niedostosowanie społeczne - (nieprzystosowanie społeczne, wykolejenie społeczne, wykolejenie przestępcze) to utrwalone i powtarzające się zachowania pozostające w sprzeczności z powszechnie uznawanymi normami (prawnymi, moralnymi, obyczajowymi), wartościami i oczekiwaniami społecznymi, które pojawiają się na skutek zaburzeń wewnętrznych, lub jako efekt niekorzystnych warunków środowiskowych4.

Niedostosowanie społeczne ma charakter uniwersalny, czyli występuje wśród młodzieży wszystkich współczesnych społeczeństw, niezależnie od geograficznych czy historyczno-kulturowych uwarunkowań.

L. Pytka ${ }^{5}$ analizując spotykane $\mathrm{w}$ literaturze przedmiotu określenia niedostosowania społecznego ujmuje je w cztery zasadnicze grupy definicji:

- definicje objawowe, w których nieprzystosowanie społeczne określa się poprzez odwołanie się do jego podstawowych i specyficznych objawów albo elementarnych wskaźników o charakterze behawioralnym;

- definicje teoretyczne, w których oprócz charakterystyki symptomatologicznej angażuje się pewne pojęcia teoretyczne, wynikające $\mathrm{z}$ ogólnej teorii przystosowania lub normalnego funkcjonowania społecznego jednostki (np. motywacja, postawy, role społeczne, przepisy ról społecznych, normy, standardy idealne, internalizacja wartości norm, poziom lęku, sumienie);

- definicje operacyjne, w których wskazuje się nie tylko na symptomy danego zjawiska (nieprzystosowania), ale przede wszystkim na sposoby jego pomiaru, odsyłając jednocześnie do konkretnego narzędzia pomiarowego (testu, skali, kwestionariusza itp.);

\footnotetext{
${ }^{2}$ G. Miłkowska, O potrzebie profesjonalnej profilaktyki w szkole, „Problemy Opiekuńczo-Wychowawcze” 2006, nr 2, s. 17.

${ }^{3}$ Hołyst, Kryminologia, Warszawa 2001, s. 646.

${ }^{4}$ L. Pytka, Pedagogika resocjalizacyjna. Wybrane zagadnienia teoretyczne, diagnostyczne i metodyczne, Warszawa 2000.

${ }^{5}$ L. Pytka, Pedagogika resocjalizacyjna. Wybrane, s. 83.
} 
- definicje utylitarne (zdroworozsądkowe, administracyjne), ujmujące nieprzystosowanie społeczne od strony pewnej bezradności środowiska wychowawczego wobec jednostki sprawiającej mu trudności wychowawcze oraz „niedostosowania" tego środowiska do potrzeb i aspiracji oraz poziomu rozwoju dziecka oznaczonego jako „zaburzone”, wobec którego należy zastosować „specjalne metody i środki".

Niedostosowanie społeczne jest problemem złożonym, którym zajmuje się pedagogika, psychologia, socjologia, kryminologia, psychiatria. Dotyczy młodych ludzi, którzy nie przekroczyli dwudziestego pierwszego roku życia. U niedostosowanych społecznie dostrzega się osłabione czynniki wolicjonalne, zmienność nastrojów, nieharmonijny rozwój uczuć, brak zainteresowań, trudności w koncentracji uwagi, niechęć do wysiłku, a także ograniczoną zdolność do przejawiania uczuć opiekuńczych, wdzięczności, przywiązania oraz przyjaźni.

Denis H. Stott oraz Jan Konopnicki ${ }^{6}$ wyróżnili cztery rodzaje niedostosowania. W każdym z nich wyróżnione zostały najistotniejsze formy zachowania się dziecka.

1) Zachowania zahamowane.

Cechy wiodące:

a) brak zaufania do ludzi, nowych rzeczy i sytuacji,

b) depresja,

c) wycofywanie się.

Dziecko jest uległe wobec innych osób, nie lubi ryzykować, boi się nowych osób i zdarzeń. W sytuacjach problemowych zachowuje się poniżej swoich możliwości intelektualnych, przegrywa $\mathrm{w}$ konkurencji. Na ogół dzieci takie nie sprawiają większych problemów wychowawczych, dlatego też nie są spostrzegane przez nauczycieli jako społecznie niedostosowane. Ze względu na poczucie nadmiernej kontroli i braku poczucia mocy, uczą się one poczucia bezradności i zależności.

2) Zachowania demonstracyjno - bojowe (wrogie).

Cechy wiodące :

a) wrogość w stosunku do dorosłych,

b) wrogość w stosunku do innych dzieci,

c) łagodniejsze formy społecznego zachowania.

Wrogość należy rozumieć jako względnie stałe nastawienie i gotowość do negatywnego ustosunkowania się do osób i rzeczy, z jakimi dziecko spotyka się w różnych sytuacjach. Nastawienie wrogie aktywizuje się pod wpływem okoliczności i przejawia się w szkodliwych dla otoczenia aktach zachowania (bójki, niesubordynacja). Agresywność występująca w środowisku domowym, szkolnym i rówieśniczym, wiąże się z niekorzystnymi oddziaływaniami środowiska, głównie w okresie wczesnego dzieciństwa. Zasadnicze znaczenie mają punitywne oddziaływania rodziców, obserwowanie agresywnych wzorów postępowania, frustracja potrzeb bezpieczeństwa, miłości i afiliacji. Wrogie zachowanie kierowane jest na osoby z najbliższego otoczenia, podlega generalizacji i przenoszeniu się na szersze środowisko społeczne, staje się początkiem przestępczości i stanowi najczęstszy typ niedostosowania. Daje największe szansę w zakresie resocjalizacji, poprzez zmianę środowiska wychowawczego.

3) Działania aspołeczne.

Cechy wiodące :

\footnotetext{
${ }^{6}$ J. Konopnicki, Niedostosowanie społeczne, Warszawa 1971, s. 21.
} 
a) brak zainteresowania oceną swoich czynów przez dorosłych,

b) brak poczucia winy,

c) nieuczciwe korzystanie z sytuacji, niekoleżeńskość.

Charakterystyczną cechą tego typu reakcji jest dążenie do szkodzenia innym, mściwość, a często i okrucieństwo. Jednostki aspołeczne odznaczają się brakiem przestrzegania elementarnych norm, przypominają osobowość socjopatyczną. Aspołeczność stanowi końcowy etap rozwoju wrogości w szczególnie niekorzystnych warunkach środowiskowych. Jednostki aspołeczne odznaczają się dużym okrucieństwem i brakiem przestrzegania elementarnych norm, są uczestnikami podkultur dewiacyjnych. Efekty resocjalizacyjne są w tym wypadku znikome.

4) Zachowania niekonsekwentne

Reakcje takiego dziecka są natychmiastowe, spontaniczne i pozbawione wcześniejszej refleksji. W związku z tym nie są one najlepszym $\mathrm{z}$ możliwych, sposobem postępowania. Wiąże się to $z$ naruszaniem przez dziecko norm społecznych. Działania niekonsekwentne można przyrównać do nadpobudliwości. Dziecko "niekonsekwentne" nie może wstrzymać się z reakcją w chwili zadziałania bodźca, nie wykorzystuje wcześniejszego doświadczenia, tym samym nie wybiera najbardziej adekwatnej realizacji zadania w określonych warunkach Reakcje te nie są przemyślane, są przypadkowe i przez to niekonsekwentne.

Tego typu zaburzenia w wychowaniu i ich przejawy są wyraźnie widoczne w instytucjach edukacyjnych i opiekuńczo-wychowawczych. Zjawiska te nie są nowe, jednakże formy jakie przyjmują są brutalne i stwarzają zagrożenie dla innych. Problem jest skomplikowany i ostatnio przybiera niebezpieczną postać, budzącą niepokój w społeczeństwie. Granica wieku osób, które wchodzą w destruktywny świat postaw ma tendencję spadkową. Wzrasta liczba nieletnich sprawców, którzy stanowią zagrożenie dla życia i zdrowia innych. Ponadto ich zachowanie cechuje brutalność oraz agresywność, jak również niepokojący fakt działania zorganizowanego.

Niedostosowanie społeczne młodych ludzi jest jednym z najtrudniejszych problemów współczesnego społeczeństwa, to wyzwanie dla instytucji edukacyjnych, opiekuńczowychowawczych, resocjalizacyjnych, mających jako główne cele i zadania: odpowiedzialność za kształcenie, wychowanie, opiekę, zdrowie i profilaktykę. Priorytetem dla tych instytucji powinno być poszukiwanie innowacyjnych metod pracy z jednostkami nieprzystosowanymi społecznie. Istotne jest, aby rozważając zmiany w systemie opieki i wychowania, zwrócić uwagę na diagnozę tego zjawiska poznając symptomy, zakres i jego uwarunkowania.

\section{Oddziaływania profilaktyczne}

Dla określenia działań pomagających zapobiegać różnym formom niedostosowania społecznego używa się kilku terminów: profilaktyka, psychoprofilaktyka, prewencja zwana też (psychologiczną prewencją). Termin psychoprofilaktyka zastąpiono w latach sześćdziesiątych XX wieku w Stanach Zjednoczonych i niektórych krajach Europy terminem prewencja, jednak te określenia nadal stosuje się wymiennie.

Profilaktyka należy do pojęć wielowymiarowych, odnosząca się do różnych obszarów i dziedzin życia jak np. oświata, wychowanie, opieka społeczna, służba zdrowia itd. Ważność i znaczenie działań profilaktycznych, wynika $\mathrm{z}$ faktu, że są korzystne pod względem ekonomicznym, ale i efektywniejsze $\mathrm{w}$ porównaniu $\mathrm{z}$ długotrwałym i nie zawsze zadowalającym leczeniem skutków różnego rodzaju problemów. 
Termin profilaktyka pochodzi od greckiego słowa phylax- stróż, prophylaktikoszapobiegawczy7. W. Okoń definiuje profilaktykę jako „ogół działań zapobiegawczych niepożądanym zjawiskom $\mathrm{w}$ rozwoju i zachowaniu się ludzi"8. Profilaktyka może mieć również charakter instytucjonalny, gdy jest prowadzona przez różne instytucje (placówki służby zdrowia, oświaty, wymiaru sprawiedliwości itd.) i charakter pozainstytucjonalny, kiedy jest realizowana w różnych interakcjach społecznych, w rodzinach, w grupach nieformalnych, w stowarzyszeniach, we wzajemnym oddziaływaniu na siebie ludzi ${ }^{9}$. Ponadto podkreśla się w literaturze, że celem działalności profilaktycznej jest zapobieganie negatywnym stanom rzeczy zarówno tym, które dopiero mają zaistnieć, jak i tym, które są w początkowej fazie istnienia.

Również w wychowaniu, podobnie jak w innych dziedzinach życia powinien skutecznie funkcjonować odpowiedni system działalności, zwany profilaktyką wychowawczą. Profilaktyka wychowawcza jest systemem działań racjonalnych, zapobiegających występowaniu i rozpowszechnianiu się zjawisk patologii społecznej, określanych jako niedostosowanie czy wykolejenie społeczne młodzieży ${ }^{10}$.

Profilaktyka niedostosowania społecznego może być realizowana na trzech poziomach. Jest to:

a) profilaktyka pierwszego stopnia (pierwszorzędowa) obejmująca środki, które umożliwiają zwalczanie zasadniczych przyczyn patologii, promocję zdrowia psychicznego fizycznego oraz przedłużanie życia człowieka,

b) profilaktyka drugiego stopnia (drugorzędowa) określająca postępowanie, które zmierza do ujawnienia i eliminowania możliwie najszybciej, wszelkiego rodzaju niedostosowań i zaburzeń osobowości, zanim nastąpi stan charakterystyczny dla danego zjawiska patologii,

c) profilaktyka trzeciego stopnia (trzeciorzędowa), oznacza interwencję, która ma na celu zapobiec komplikacjom i następstwom społecznym z powodu wystąpienia stanu dewiacji11.

Przyjmuje się, że profilaktyka pierwszorzędowa realizowana jest intensywnie w szkołach $\mathrm{w}$ formie informacyjno-edukacyjnej. Na drugim miejscu jest profilaktyka drugorzędowa, która koncentruje się na grupach wysokiego ryzyka i może być również realizowana w szkołach. Natomiast profilaktyka trzeciorzędowa jest realizowana $\mathrm{w}$ formie programów terapeutycznych dla osób przejawiających zachowania patologiczne i jest prowadzona przez placówki specjalistyczne.

Przedstawiona kategoryzacja jest najbardziej znana, ponieważ uwzględnia poziom funkcjonalności czy dysfunkcjonalności odbiorców profilaktyki.

We współczesnej literaturze i praktyce społecznej przyjęty jest również inny podział działań profilaktycznych. Zbigniew Gaś12 wyróżnia profilaktykę uniwersalną, selektywną

\footnotetext{
${ }^{7}$ B. Górecki, Historia i miejsce profilaktyki w pediatrii, [w:] B. Wojnarowska (red.), Profilaktyka w pediatrii, Warszawa 1998, s. 225.

${ }^{8}$ W. Okoń, Stownik Pedagogiczny, Warszawa 1992, s. 228.

${ }^{9}$ Z. Ostrihańska, Losy uczniów nieprzystosowanych społecznie, Lublin 1997, s. 153.

${ }^{10}$ L. Pytka, Profilaktyka wykolejenia społecznego, [w:] W. Pomykało (red.), Encyklopedia Pedagogiczna, Warszawa 1993, s. 630.

11 Jedlewski, Młodzież niedostosowana społecznie, [w:] W. Pomykało (red.), Encyklopedia Pedagogiczna, Warszawa 1993, s. 379-380.

${ }^{12}$ Z. Gaś, Profilaktyka w szkole, Warszawa 2006, s. 36-37.
} 
i zalecaną (wskazującą). Podobnie jak w przypadku profilaktyki pierwszorzędowej, profilaktyka uniwersalna ma na celu przeciwdziałanie pierwszym próbom podejmowania zachowań ryzykownych lub opóźnienie inicjacji. Działania z zakresu profilaktyki uniwersalnej realizowane są przede wszystkim przez nauczycieli, pedagogów i psychologów szkolnych i są kierowane do wszystkich osób w określonej populacji (np. wszystkich uczniów w szkole), bez względu na ich poziom zagrożenia dysfunkcją.

Celem profilaktyki selektywnej jest tworzenie warunków, które umożliwiają wycofanie się z zachowań ryzykownych. Działania w zakresie profilaktyki selektywnej są kierowane do wybranych podgrup w ogólnej populacji, identyfikowanych na zasadzie poziomu zagrożenia dysfunkcją. Mogą być prowadzone przez psychologów i pedagogów szkolnych, specjalistów w poradniach psychologiczno-pedagogicznych oraz wykwalifikowanych realizatorów programów profilaktycznych.

Natomiast profilaktyka zalecana skierowana jest do grupy, w której rozwinęły się już symptomy zaburzeń, głównie związane z uzależnieniem od substancji psychoaktywnych. Obejmuje ona działania interwencyjne i terapeutyczne, mające na celu zablokowanie pogłębiania się zaburzeń i zachowań destrukcyjnych oraz umożliwienie powrotu do prawidłowego funkcjonowania społecznego. Takie działania można nazwać resocjalizacyjnymi.

\section{Oddziaływania prewencyjne}

Pojęcie prewencji nie jest jednoznacznie rozumiane przez autorów zajmujących się tym zagadnieniem, odnosi się do różnych działań, w których wykorzystuje się metody i środki psychologiczne w celu zapobiegania niekorzystnym zjawiskom wżyciu człowieka, powodującym zaburzenia $\mathrm{w}$ jego funkcjonowaniu somatycznym, psychicznym i społecznym. G. Caplan ${ }^{13}$ zaproponował podział prewencji na:

prewencję pierwotną, obejmującą starania zmierzające do zmniejszenia prawdopodobieństwa wystąpienia zaburzeń poprzez przeciwdziałanie szkodliwym warunkom, zanim wywołają one zaburzenia;

- - prewencję wtórną( drugiego stopnia), stosowaną, gdy wykryte zostaną wczesne sygnały zaburzeń, ma ona na celu powstrzymanie rozwoju zaburzeń i skrócenie czasu ich trwania;

- - prewencję trzeciego stopnia, mającą na celu zapobieganie skutkom zaburzeń lub przebytej choroby oraz przeciwdziałanie ich nawrotom, a także minimalizację wywoływanych nimi uszkodzeń.

Współczesna literatura z zakresu psychologii prewencji zajmuje się w zasadzie tylko prewencją pierwotną czyli właściwą. Skupia swoją uwagę na grupach i jednostkach ryzyka, u których istnieje podwyższone prawdopodobieństwo zaburzeń.

Prewencję można rozpatrywać przez pryzmat dwóch głównych strategii postępowania14:

1) wzmacnianie kompetencji ludzi przez wyposażenie ich w umiejętności i uodparnianie oraz

2) organizowanie otoczenia tak, by sprzyjało rozwojowi i nie zawierało źródeł stresu.

Chcąc osiągnąć pożądane efekty, strategie te powinny być stosowane równolegle tzn. stymulowanie rozwoju osoby poprzez wpływ bezpośredni i przez wpływ na otoczenie

\footnotetext{
${ }^{13}$ G. Caplan, Principles ofpreventive psychiatry,[w:] H. Sęk (red.), Społeczna psychologia kliniczna, Warszawa 2014, s. 476.

${ }^{14}$ H. Sęk (red.), Spoleczna psychologia kliniczna, Warszawa 2014, s. 477.
} 
w którym jednostka przebywa. Jest to możliwe tylko przy znajomości praw psychologii rozwój owej.

Z. Gaś15 omawiając działania profilaktyki pierwszorzędowej, kierowanej do ludzi zdrowych i wspomagającej prawidłowe procesy rozwoju psychospołecznego, podkreśla, iż opierają się one na powszechnie obowiązujących prawidłowościach rozwojowych (fizycznych, psychicznych, społecznych). Również konstruowanie programów profilaktycznych wymaga znajomości potrzeb rozwojowych człowieka (z uwzględnieniem wieku, płci, pełnionych ról, kontekstu kulturowego itp.).

Podobnej znajomości zagadnień rozwoju wymagają oddziaływania profilaktyki drugorzędowej, której celem jest powstrzymywanie procesów niedostosowania społecznego i przywrócenie zdrowego rozwoju.

Rozumienie znaczenia występującej korelacji pomiędzy profilaktyką a prewencją jest istotne dla skuteczności działań podejmowanych w celu minimalizowania niedostosowania społecznego wśród dzieci i młodzieży.

\section{Podsumowanie}

Przedstawione rozważania na temat problemu niedostosowania społecznego dzieci i młodzieży oraz działań profilaktycznych i prewencyjnych $\mathrm{w}$ tym obszarze są niezmiernie istotnym zagadnieniem we współczesnej szkole. Wydaje się zasadne monitorowanie prowadzonej winstytucjach oświatowych profilaktyki niedostosowania społecznego realizowanej poprzez Szkolne Programy Profilaktyczne pod kątem spełniania wymagań, oczekiwań oraz określonych standardów jakości, gdyż od tych działań w dużym stopniu zależy przyszłość pokoleń.

Uwzględnienie wieku, stopnia rozwoju i poziomu wrażliwości emocjonalnej adresatów profilaktyki i prewencji jest szczególnie istotne w przypadku oddziaływań na dzieci i młodzież. Brak wiedzy $w$ tym zakresie może spowodować, że słuszne w założeniach działania okażą się nieskuteczne lub szkodliwe dla odbiorców.

Analiza stanu faktycznego w obszarze oddziaływań profilaktycznych jak również własne doświadczenia zawodowe $\mathrm{w}$ tym zakresie, pokazują jak wiele zagadnień wymaga zmiany, nowego spojrzenia, przemodelowania w celu zwiększenia ich skuteczności. Działania takie obejmują wiele płaszczyzn i wymagają współpracy wielu specjalistów z różnych dziedzin jak np. pedagogika, psychologia, resocjalizacja. Celowym jest dążenie do modyfikacji istniejących już rozwiązań a także wielopłaszczyznowe podejście i holistyczne ujęcie profilaktyki, które może podnieść skuteczność podejmowanych działań w procesie wychowania.

\section{Bibliografia:}

Caplan G., Principles of preventive psychiatry, [w:] H. Sęk (red.), Społeczna psychologia kliniczna, PWN, Warszawa 2014.

Gaś Z., Profilaktyka w szkole, Warszawa 2006.

Górecki B., Historia i miejsce profilaktyki w pediatrii, [w:] B. Wojnarowska (red.)

Hołyst B., Kryminologia, Wyd. Lexis Nexis, Warszawa 2001.

Jedlewski S., Młodzież niedostosowana społecznie, [w:] W. Pomykało (red.) Encyklopedia Pedagogiczna, Warszawa 1993.

Konopnicki J., Niedostosowanie społeczne, PWN, Warszawa 1971.

Okoń W, Słownik Pedagogiczny, PWN Warszawa 1992.

Ostrihańska Z., Losy uczniów nieprzystosowanych społecznie, Wyd. KUL, Lublin 1997.

\footnotetext{
${ }^{15}$ Z. Gaś, Profilaktyka, s. 37-47.
} 
Profilaktyka w pediatrii, Wyd. Lekarskie PZWL, Warszawa 1998.

Pytka L., Pedagogika resocjalizacyjna. Wybrane zagadnienia teoretyczne, diagnostyczne i metodyczne, Wydawnictwo APS, Warszawa 2000. 